\title{
$\mathrm{Al}-\mathrm{Ag}$ 系 反応拉 散
}

\section{山根 寿己*・高橋 純造*・屋鋪 裕義**}

\author{
Reaction-diffusion in the $\mathrm{Al}-\mathrm{Ag}$ system
}

UDC 669.716.9:669.25. $058: 669.24 .058$

YAMANE Toshimi*, TAKAHASHI Junzo* and YASHIKI Hiroyoshi**

Reaction-diffusion of the $\mathrm{Al}-\mathrm{Ag}$ system was investigated by the electron probe micro-analysis. Experimental results obtained were as follows.

(1) Intermediate phases $\zeta$ and $\mu$ were formed by the diffusion between aluminum and silver.

(2) Thickness of the $\zeta$ phase was expressed by the equation of $W=k \sqrt{t}$, where $t$ was the diffusion time and $k$ the growth rate constant. And the $k$ was expressed as follows.

$$
\begin{aligned}
& k_{1}^{2}=3.1 \times 10^{-1} \exp (-28000 / R T) \mathrm{cm}^{2} / \mathrm{sec} \quad\left(360^{\circ} \mathrm{C} \sim 440^{\circ} \mathrm{C}: \zeta \text { and } \mu \text { phases }\right) \\
& k_{2}^{2}=6.6 \times 10^{-1} \exp (-29000 / R T) \mathrm{cm}^{2} / \mathrm{sec} \quad\left(480^{\circ} \mathrm{C} \sim 560^{\circ} \mathrm{C} \text { : only } \zeta \text { phase }\right) \\
& k_{3}^{2}=2.6 \times 10^{-1} \exp (-28000 / R T) \mathrm{cm}^{2} / \mathrm{sec} \quad\left(360^{\circ} \mathrm{C} \sim 560^{\circ} \mathrm{C}\right. \text { : all temperature range measured). }
\end{aligned}
$$

(3) Interdiffusion coefficients in the $\zeta$ phase were expressed as follows.

$$
\begin{array}{ll}
D_{1}=2.1 \times 10^{-1} \exp (-27000 / R T) \mathrm{cm}^{2} / \mathrm{sec} & \left(360^{\circ} \mathrm{C} \sim 440^{\circ} \mathrm{C}: \zeta \text { and } \mu \text { phases }\right) \\
D_{2}=2.1 \times 10^{-1} \exp (-27000 / R T) \mathrm{cm}^{2} / \mathrm{sec} & \left(480^{\circ} \mathrm{C} \sim 560^{\circ} \mathrm{C}: \text { only } \zeta \text { phase }\right) \\
D_{3}=2.5 \times 10^{-1} \exp (-27000 / R T) \mathrm{cm}^{2} / \mathrm{sec} & \left(360^{\circ} \mathrm{C} \sim 560^{\circ} \mathrm{C}: \text { all temperature range measured }\right) .
\end{array}
$$

(4) It was shown by the Kirkendal effect that aluminum diffused faster than silver.

(Received January 9, 1975)

\section{1. 緒言}

2 元系で拡散領域に中間相が生成する反応拡散によ り，拡散領域の状態を調べる実験は，今日までしばしば 行なわれてきた。その場合生成された中間相のうち, 特 定の相のみが優先的に成長する場合が多い1。 また 2 元 系の平衡状態図から予想される中間相が全部現われる場 合2) むあれば，一部しか現われない場合3)もある。そし て状態図中にある中間相が全く現われない場合4)や，平 衡状態図中に存在しないような相が生成される場合5)も ある。しかしまだこらいつた実験を統一的に説明するに は至つていない。

本研究は最近よく行なわれている E.P.M.A.による拡 散対の拡散領域の濃度分析により，まだほとんど実験の 行なわれていない $\mathrm{Al}-\mathrm{Ag}$ 系の反応拡散を調べたもので ある。アルミニウム系における反応拡散の実験は, $\mathrm{Al}-\mathrm{Zr}$

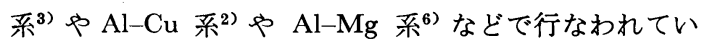
る。その結果 $\mathrm{Al}-\mathrm{Cu}$ 系と $\mathrm{Al}-\mathrm{Mg}$ 系では, 平衡状態図 から予想される中間相が全部生成されたが, $\mathrm{Al}-\mathrm{Zr}$ 系で は平衡状態図中に 4 種の中間相が存在するのに, 1 種し
か生成されなかつた。

$\mathrm{Al}-\mathrm{Ag}$ 系の拡散の実験は, アルミニウムの $\alpha$ 固溶体で の相互拡散係数の測定 ${ }^{7)}$ や，アルミニウムとアルミニウ ムの $\alpha$ 固溶体での銀トレーサーを使った銀の拡散係数の 測定 $^{8), 9)}$ などがある。その他には中間相の生成された拡 散領域での硬度の測定 ${ }^{10), 11)}$ などがある。しかし，こ の $\mathrm{Al}-\mathrm{Ag}$ 系合金は析出現象があり, 実用上も重要な合 金系でもあるにもかかわらずその反応拡散の中間相の相 成長状態や，中間相における，相互拡散係数などについ ては全く測定されていない。

Fig. 1 の $\mathrm{Ag}-\mathrm{Al}$ 系の平衡状態図 ${ }^{12)}$ において $448^{\circ} \mathrm{C}$ 以下 の温度で 相と $\mu$ 相という 2 つの中間相が存在し, $448^{\circ} \mathrm{C}$ から $610^{\circ} \mathrm{C}$ の温度範囲では中間相はら相だけが存在する ことがわかる。中間相の結晶構造は，ら相が h.c.p. 構 造12)であり， $\mu$ 相は $\beta-\mathrm{Mn}$ 型12)である。本研究では純 アルミニウムと純銀の拡散対により， $360^{\circ} \mathrm{C} \sim 560^{\circ} \mathrm{C}$ の温 度範囲で反応拡散を行なつた。そして平衡状態図中で $\zeta ，$ $\mu$ 両相が存在するときと, ら相のみが存在するときとで のら相の成長状態の違いや, 各温度でのら相の相互拡散 係数の測定や，カーケンドール効果について調ベた。 


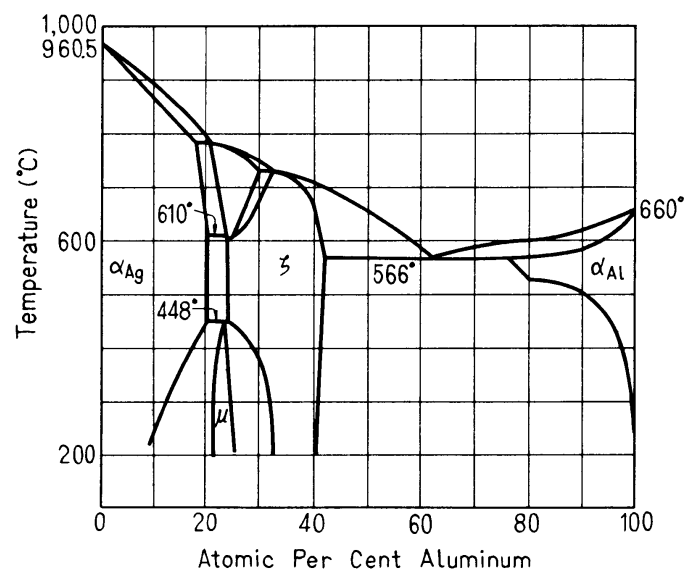

Fig. 1 Equilibrium phase diagram of the $\mathrm{Ag}-\mathrm{Al}$ system.

\section{2. 実験方法}

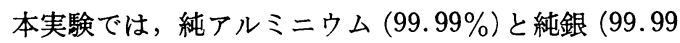
\%)を接合させた拡散対を使つた。アルミニウムはイン ゴットを冷間圧延し, 厚さ約 $4.5 \mathrm{~mm}$, 幅約 $38 \mathrm{~mm}$ の板 にした。銀は粒状のものを, 黒鉛ルツボを使い, 表面を 黒鉛粉でおおつて溶解し, 鋳造後冷間圧延を行なつて, 厚さ約 $3 \mathrm{~mm}$, 幅約 $15 \mathrm{~mm}$ の板にした。そして結晶粒を 大きくして，粒界拡散の影響をできるだけ少なくするた め，アルミニウムはアルゴン零囲気中で $550^{\circ} \mathrm{C}$ で48時間 の焼鈍を行ない, 銀はシリカチューブに入れて, 真空にし て $800^{\circ} \mathrm{C}$ で24時間の焼鈍を行なつた。焼鈍後の結晶粒の 半径は, アルミニウム板が約 $1.5 \mathrm{~mm}$, 銀板が約 $0.3 \mathrm{~mm}$ である。アルミニウム板と銀板をエメリー紙で，次にバ フで研摩を行ない, アルミニウム板はさらに電解研摩を 行なつた。拡散対はこのようにしてできたアルミニウム 板と銀板を $\mathrm{Al}|\mathrm{Ag}| \mathrm{Al}$ の順に重ねたサンドイッチ構造に して, $300^{\circ} \mathrm{C}$ で 5 分間加熱した後圧延により接合した。 できた拡散対は帯状で，厚さは約 $4 \mathrm{~mm}$ である。使用す

Table 1 Diffusion conditions

\begin{tabular}{c|l|l|l|l|l|l|l|l|l}
\hline $\begin{array}{c}\text { Diffusion } \\
\text { temperature } \\
\left({ }^{\circ} \mathrm{C}\right)\end{array}$ & \multicolumn{7}{|c}{ Diffusion time (hr) } \\
\hline 560 & 0.5 & 1 & 2 & 4 & 8.5 & 16 & & & \\
540 & 0.5 & 1 & 2 & 4 & 8 & 16 & & & \\
520 & 0.5 & 1 & 2 & 4 & 8 & 16 & 32 & 64 & \\
500 & 0.5 & 1 & 2 & 4 & 8 & 16 & 32 & 64 & \\
480 & & & & 4 & 8 & 16 & 32 & 64 & \\
440 & & & & 4 & 8 & 16 & 32 & 64 & 128 \\
400 & & & & 4 & 8 & 16 & 32 & 64 & 128 \\
360 & & & & 4.2 & 8 & 16 & 32 & 64 & 128 \\
\hline
\end{tabular}

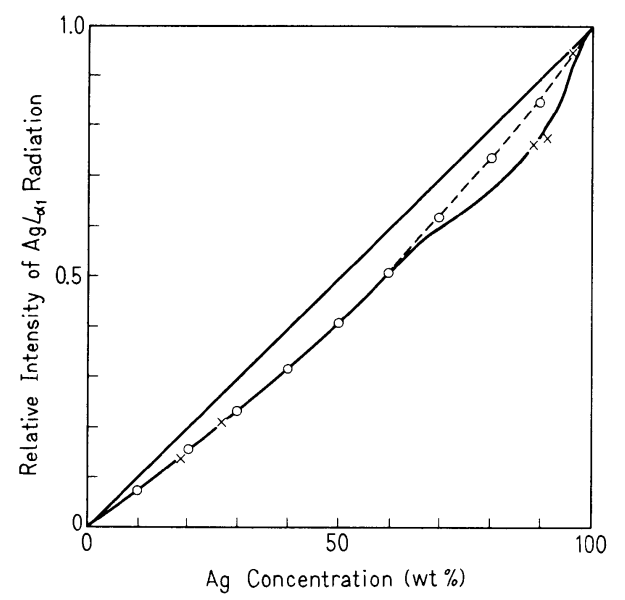

$\bigcirc$ : Calculation value.

$X$ : Calibrated value with standard specimens.

Fig. 2 Standard calibration curve for $\operatorname{AgL} \alpha_{1}$ radiation for E.P.M.A.

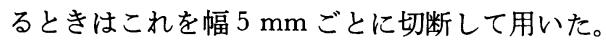

拡散焼鈍は水素ガス中で $360^{\circ} \mathrm{C} \sim 560^{\circ} \mathrm{C}$ の 温度範囲で 0.5時間から128時間までの各々の時間行なつた。Table 1 に拡散焼鈍の温度と時間を示してある。拡散焼鈍後, 水焼入を行なつたのち拡散方向に平行に拡散対を切断し その表面をエメリー紙とバフで研摩した。そして拡散領 域を光学顕微鏡と E.P.M.A. で観察した。濃度分析は加 速電圧 $25 \mathrm{kV}$ の E.P.M.A. を使つた。E.P.M.A.の濃度 補正のための補正用検量曲線は, 標準試料の E.P.M.A. による分析と, 計算より求めたもの ${ }^{13)}$ とで決めた。Fig. 2 がこの検量曲線であり，本実験では実線部分で補正を 行なつた。

カーケンドール効果の測定には, 拡散焼鈍前に拡散対 の表面での $\mathrm{Al} \mid \mathrm{Ag}$ 界面の位置を微少硬度計のマイクロ メーターで測定し, 扡散焼鈍後に再び元の界面の位置を 測定してその移動を調べた。界面はアルミニウムの酸化 皮膜らしい介在物により確認できた。Photo 1 と 2 の矢 印が元の界面の位置である。

生成された中間相のらち，ら相はデバイ・シェラーX 線回折法により,その結晶構造を確認し, 格子定数を測 定した。

\section{3. 実験 結 果 \\ 3.1 拡散領域の状態}

Photo 1 は $400^{\circ} \mathrm{C} て ゙ 128$ 時間の拡散焼鈍を行なつた拡散 対の顕微鏡写真である。 $360^{\circ} \mathrm{C} \sim 440^{\circ} \mathrm{C}$ 温度範囲で拡散 焼鈍を行なつた拡散対は, すべて Photo 1 のようにら相 と $\mu$ 相が生成されていることがわかつた。 Photo 2 は $520^{\circ} \mathrm{C}$ で 4 時間の拡散焼鈍を行なつた拡散対の顕微鏡写 
Vol. 25, No. 5

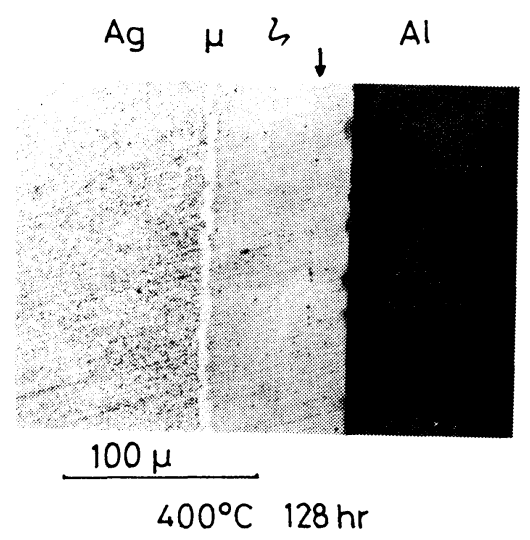

Photo 1 Typical photomicrograph of the diffusion zone in $\mathrm{Al}-\mathrm{Ag}$ couples diffused at $360^{\circ} \mathrm{C} \sim$ $440^{\circ} \mathrm{C}$.

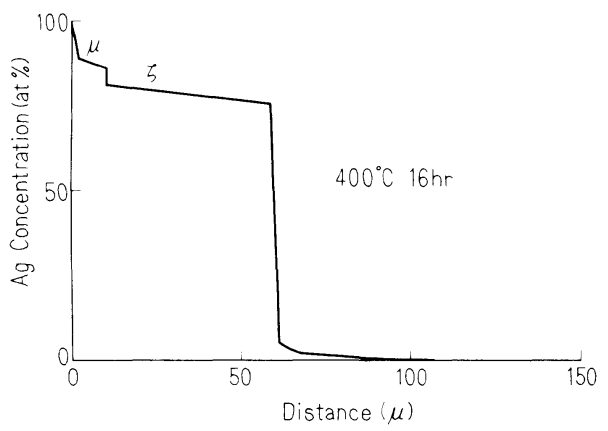

Fig. 3 Typical concentration-penetration curve of Al-Ag couples diffused at $360^{\circ} \mathrm{C} \sim 440^{\circ} \mathrm{C}$.

真である。 $480^{\circ} \mathrm{C} \sim 560^{\circ} \mathrm{C}$ の温度範囲で搪散焼鈍を行なつ た抬散対は，すべて Photo 2 のように いることがわかつた。Fig. 3 は $400{ }^{\circ} \mathrm{C} て ゙ 16$ 時間の拡散焼 鈍を行なつた抬散対の濃度を E.P.M.A. で分析した濃 度一距離曲線である。このように $360^{\circ} \mathrm{C} \sim 440^{\circ} \mathrm{C}$ の温度範

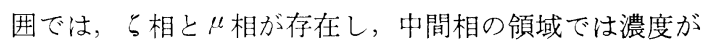

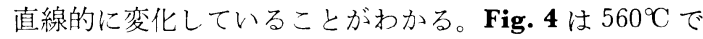
0.5時間の㹡散焼鈍を行なつた挔散対の濃度を E.P.M.A. で分析した濃度-距離曲線で， $480^{\circ} \mathrm{C} \sim 560^{\circ} \mathrm{C}$ の温度範囲 ではら相が存在し，ら相内では濃度がこの場合も直線的 に変化していることがわかる。このように本実験では， 平衡状態図でら相と $\mu$ 相という 2 つの中間相が存在する

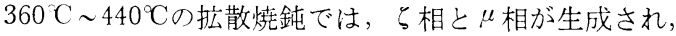
平衡状態図でら相だけが中間相として存在する $480^{\circ} \mathrm{C} \sim$ $560^{\circ} \mathrm{C}$ の抬散焼鈍ではら相が生成され，それぞれ平衡状 態図から予想された通りに中間相が生成されることがわ かつた。

ら相については，昖散焼鈍後の試料から検查粉末をと

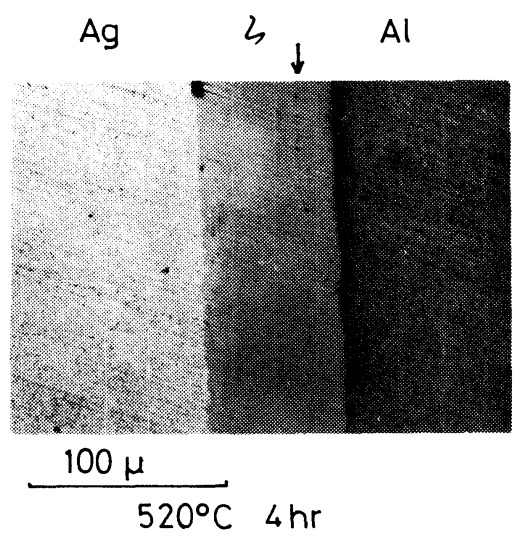

Photo 2 Typical photomicrograph of the diffusion zone in $\mathrm{Al}-\mathrm{Ag}$ couples diffused at $480^{\circ} \mathrm{C} \sim$ $560^{\circ} \mathrm{C}$.

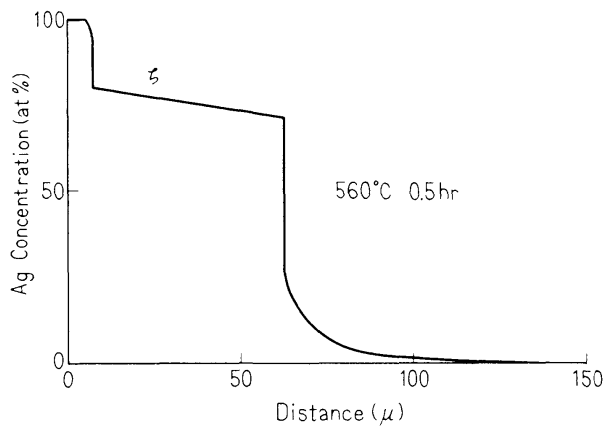

Fig. 4 Typical concentration-penetration curve of $\mathrm{Al}-\mathrm{Ag}$ couples diffused at $480^{\circ} \mathrm{C} \sim 560^{\circ} \mathrm{C}$.

り，デバィ・シェラーX線回析法により h.c.p. 構造であ ることと，その格子定数を测定した。a 軸と $\mathrm{c}$ 軸の測定 值は $\mathrm{a}=2.897 \AA ， \mathrm{c}=4.610 \AA$ であつた。これによつて ら相であることを確認した。 $\mu$ 相はPhoto 1 からもわか るように，相の厚さが薄く，検查粉末がとれなかつたの で, 結晶構造の確認は省略した。

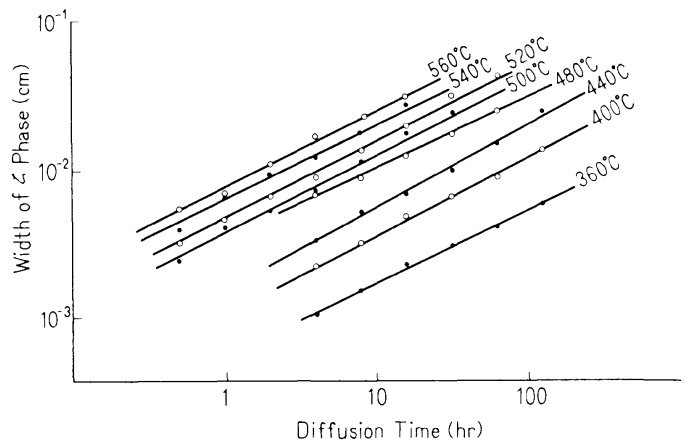

Fig. 5 Logarithmic plot of growth of $\zeta$ phase in diffusion couples. 


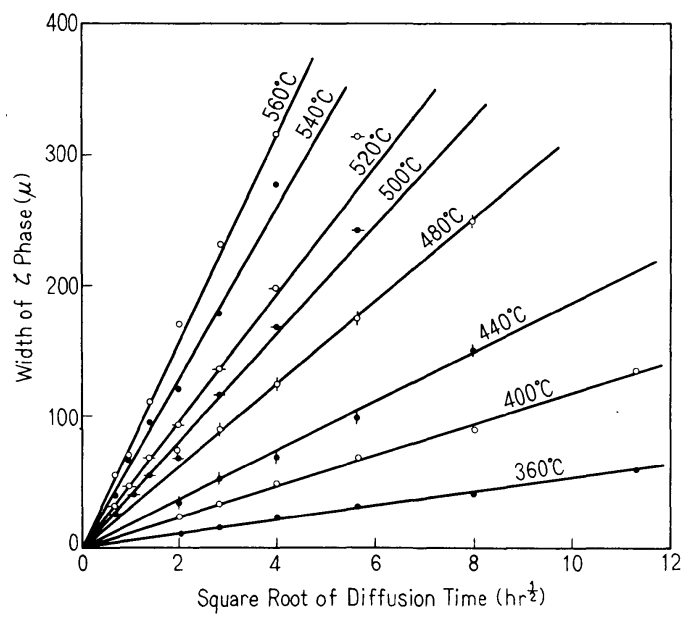

Fig. 6 Growth of $\zeta$ phase in diffusion couples.

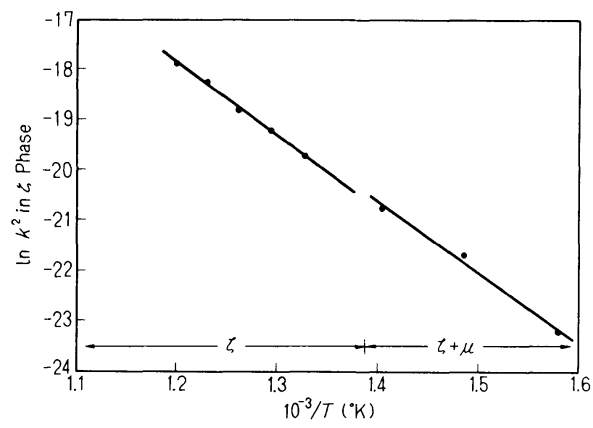

Fig. 7 Temperature dependence of the growth of $\zeta$ phase.

\section{2 相成長}

Fig. 5 はら相の相成長の状態を調べるために，相の厚 さと時間を対数でプロットしたものである。このように $360^{\circ} \mathrm{C}$ から $560^{\circ} \mathrm{C}$ 各温度でそれぞれ直線上にのり，その 直線の傾きがほぼ 0.5 であるから, 放物線則が成り立つ ことがわかる。これより拡散が体積拡散に支配されてい ることがわかる。Fig. 6 はら相の相成長が放物線則に従 らことから，縦軸に相の厚さ，横軸に抗散焼鈍時間の平 方根をとつてプロットしたものである。このようにそれ ぞれの温度で拡散させても直線関係がえられている。一 般に放物線則は相の厚さを $W$ ，拡散焼鈍時間を $t$ とする と次のように表わせる。

$$
W=k \sqrt{\bar{t}} \quad(k \text { は相成長の速度定数 })
$$

次にら相の相成長の温度依存性を調べるために, 式(1) の $k$ を使つて， $k^{2}$ をンニウス・プロットしたのが Fig. 7 である。ここで $k$ の代わりに $k^{2}$ を使つたのは, 拡散 係数と比較するときに, 次元が等しくなり都合が良いか らである。Fig. 7 ではら相と $\mu$ 相が生成された $360^{\circ} \mathrm{C} \sim$

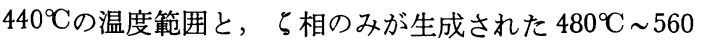

${ }^{\circ} \mathrm{C}$ 温度範囲で別々に最小 2 乗法で直線が引いてある。

Fig. 7 より 相の相成長は次式で表わされる。

$$
\begin{aligned}
k_{1}^{2}= & 3.1 \times 10^{-1} \exp (-28000 / R T) \mathrm{cm}^{2} / \mathrm{sec} \\
& \left(360^{\circ} \mathrm{C} \sim 440^{\circ} \mathrm{C}: \zeta \text { 相と } \mu \text { 相が共存 }\right) \\
k_{2}^{2}= & 6.6 \times 10^{-1} \exp (-29000 / R T) \mathrm{cm}^{2} / \mathrm{sec} \\
& \left(480^{\circ} \mathrm{C} \sim 560^{\circ} \mathrm{C}: \zeta \text { 相だけが存在 }\right) \\
k_{3}^{2}= & 2.6 \times 10^{-1} \exp (-28000 / R T) \mathrm{cm}^{2} / \mathrm{sec} \\
& \left(360^{\circ} \mathrm{C} \sim 560^{\circ} \mathrm{C}: \text { 全温度範囲 }\right)
\end{aligned}
$$

ここで $R$ がガス定数であり， $T$ は絶対温度である。式(2) と(3)でわかるよらにら相と $\mu$ 相の両相が共存するときも ら相だけが存在するときも同じような温度依存性をも ち，活性化エネルギーの值も実験の誤差内では等しいと みなすことができる。そこで Fig. 7 では全温度範囲で最 小自乗法で直線関係が成立すると思われるので，式(4)の よらに全温度範囲での相成長も示した。

$\mu$ 相の成長は，等しい拡散焼鈍時間で高温のときより 低温の拡散温度のとき成長が速い場合があり，また放物 線則にも従わなかった。相の厚さも Photo 1 かからわか るように薄く，本実験の拡散焼鈍時間ではほとんど $10 \mu$ 以下であつた。そのためくわしい相成長の状態は測定で きなかつた。

\section{3 相互拡散係数}

ら相の相互拡散係数を求めるために, Heumann ${ }^{14)}$ が 導入した式を用いた。この式は，中間相での濃度が端か ら端までほぼ直線的に変化しているような拡散に対し て有効な式である。Heumann の式は次のように表わせ る。

$$
D_{i}=-\frac{W_{i}}{2 t \cdot \Delta C_{i}} \int_{0}^{C_{i}^{\frac{1}{2}}} x d C
$$

ここで $i$ は $i$ 番目の中間相であることを表わし， $D_{i}$ は 相互拡散係数, $W_{i}$ は中間相の厚さ, $\Delta C_{i}$ は中間相の両 端の濃度差, $C_{i}^{\frac{1}{2}}$ は中間相内の濃度-距離曲線の中央の濃 度， $x$ は俣野界面からの距離， $t$ は拡散焼鈍時間を表わ す。Fig. 3 と Fig. 4 より本実験では 5 相内で濃度が直線 的に変化しているので，式(5)を用いることができる。こ の式より求めた $D_{i}$ は, 中間相内での平均の相互拡散係

Table 2 Interdiffusion coefficients in $\zeta$ phase

\begin{tabular}{c|c}
\hline \hline Temperature $\left({ }^{\circ} \mathrm{C}\right)$ & $D\left(\mathrm{~cm}^{2} / \mathrm{sec}\right)$ \\
\hline 560 & $2.2 \times 10^{-8}$ \\
540 & $1.9 \times 10^{-8}$ \\
520 & $8.8 \times 10^{-9}$ \\
500 & $6.6 \times 10^{-9}$ \\
480 & $4.4 \times 10^{-9}$ \\
440 & $1.4 \times 10^{-9}$ \\
400 & $5.6 \times 10^{-10}$ \\
360 & $1.3 \times 10^{-10}$ \\
\hline
\end{tabular}




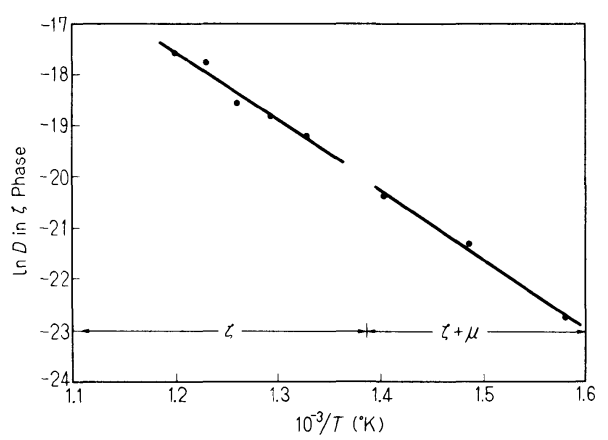

Fig. 8 Temperature dependence of the interdiffusion coefficients of $\zeta$ phase.

数を表わしている。一般に Heumannの式は, 中間相内 での濃度変化に伴つて，モル体積が変化するときには使 えない。しかし Al-Ag 系ではアルミニウムのモル体積 が， $10.0 \mathrm{~cm}^{3} / \mathrm{mol}$ で銀が $10.3 \mathrm{~cm}^{3} / \mathrm{mol}$ とほとんど同 じである。そして他の文献 ${ }^{15), 16)}$ から $\mathrm{Al}-\mathrm{Ag}$ 系では，濃 度変化による格子定数の変化が少なく，モル体積の変化 が $10.0 \mathrm{~cm}^{3} / \mathrm{mol}$ から $10.3 \mathrm{~cm}^{3} / \mathrm{mol}$ の間に入ることがわ かつた。したがつて濃度変化に対して，モル体積は一定 と考えて Heumannの式を用いた。式(5)より求めたら相 での相互拡散係数の值は, Table 2 のようになる。

次にら相での相互挔散係数の温度依存性を調べたのが

Fig. 8 でああ。Fig. 8 では，相成長の温度依存性を調べ た場合と同様に，ら相と $\mu$ 相が生成している $360^{\circ} \mathrm{C} \sim 440$ ${ }^{\circ} \mathrm{C}$ 温度範囲と, $\zeta$ 相のみが生成している $480^{\circ} \mathrm{C} \sim 560^{\circ} \mathrm{C}$ の温度範囲で別々に最小自乗法で直線を引いた。各温度 範囲でのら相の相互拡散係数の温度依存性は次のように 表わせる。

$$
\begin{aligned}
D_{1}= & 2.1 \times 10^{-1} \exp (-27000 / R T) \mathrm{cm}^{2} / \mathrm{sec} \\
& \left(360^{\circ} \mathrm{C} \sim 440^{\circ} \mathrm{C}: \zeta \text { 相と } \mu \text { 相が共存 }\right) \\
D_{2}= & 2.1 \times 10^{-1} \exp (-27000 / R T) \mathrm{cm}^{2} / \mathrm{sec} \\
& \left(480^{\circ} \mathrm{C} \sim 560^{\circ} \mathrm{C}: \zeta \text { 相だけが存在 }\right) \\
D_{3}= & 2.5 \times 10^{-1} \exp (-27000 / R T) \mathrm{cm}^{2} / \mathrm{sec} \\
& \left(360^{\circ} \mathrm{C} \sim 560^{\circ} \mathrm{C}: \text { 全温度範囲 }\right)
\end{aligned}
$$

式(6)と(7)からわかるようにら相と $\mu$ 相が共存するときで

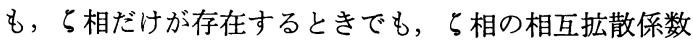
は同じ温度依存性をもち活性化ェネルギーの值も等し い。Fig. 8 では全温度範囲で最小自乗法により直線を引 くことができる。式(8)にこの全温度範囲でのら相の相互 拡散係数の温度依存性を示している。

\section{4 カーケンドール効果}

元の界面はアルミニウム側に移動していた。これより アルミニウムの方が銀より速く扩散することがわかつ た。

\section{4. 考察}

\section{1 中間相の生成状態亡相互拡散係数}

本実験では平衡状態図から予想された中間相が，各温 度で生成された。また $\mu$ 相の成長はら相に比べて非常に 遅かつた。このように特定の相のみが優先的に成長する ことは, 緒言で述べた通り，よく報告されている1)。

ら相の相成長は放物線則に従うことがわかつたが, Kidson ${ }^{17)}$ は Fick の第 1 法則から，放物線則を次式のよ らに表わしている。

$$
\begin{aligned}
W_{i}= & 2\left[\left\{\frac{(D K)_{i+1, i}-(D K)_{i, i+1}}{C_{i, i+1}-C_{i+1, i}}\right\}\right. \\
& \left.-\left\{\frac{(D K)_{i, i-1}-(D K)_{i-1, i}}{C_{i-1, i}-C_{i, i-1}}\right\}\right] \sqrt{ } \bar{t} \\
= & k_{i} \sqrt{t}
\end{aligned}
$$

ここで $W_{i}$ は $i$ 番目の相の厚さ, $C_{i, i+1}$ は濃度, $D_{i, i+1}$ は相互拡散係数, $K_{i, i+1}=\sqrt{t}\left(\frac{d C}{d x}\right)_{i, i+1},(i, i+1)$ は $i$ 番目の相における， $i$ 番目と $i+1$ 番目の界面を表わ す。式(9)からもわかるよらに，ある特定の相の成長は， その相の拡散係数や濃度だけでなく, その両端に存在す る他相の拡散係数や濃度との相互関係により決まるもの

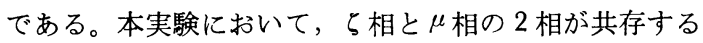

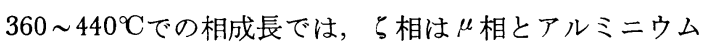
の $\alpha$ 固溶体の 2 相にはさまれている。そしてら相だけが

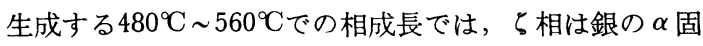
溶体とアルミニウムの $\alpha$ 固溶体にはさまれている。した

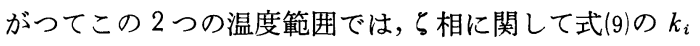
の内容は本質的に違つたものである。ところが本実験で は, Fig. 7 や式(2) (4)からわかるとおり，この 2 つの温 度範囲での相成長の温度依存性は等しく，ら相の成長は $\mu$ 相が存在しても，しなくても見かけ上かわらないこと になる。

次に式(1)の $k^{2}$ の温度依存性から求めた相成長の活性 化エネルギーは, 式(2)〜 (4)から $28000 \mathrm{cal} \sim 29000 \mathrm{cal}$ で あり，拡散の活性化エネルギーは，式(6) (8)から 27000 cal である。これは実験誤差を考慮すると，ほぼ等しい とみなすことができる。相成長の速度定数 $k$ は Kidson が導入した式(9)の $k_{i}$ に相当するわけであるが，この式 (9)からわかるとおり，ki して複雑な温度依存性がある。したがつて一般に相成長 の活性化エネルギーと拡散の活性化エネルギーは一致し ない。そしてこの 2 つの活性化エネルギーの相違は, 中 間相の固溶領域に温度依存性があるためと考えられてい る。船水と渡辺 ${ }^{18)}$ は，この 2 つの活性化エネルギーの相 違を次のよらに関係づけている。

$$
Q_{k \beta}^{2}=Q_{D \beta}+Q_{g}
$$


ここで $Q_{k \beta}^{2}$ は $\beta$ 相の相成長の融性化エネルギー， $Q_{D \beta}$ は $\beta$ 相の拡散の活性化エネルギー， $\quad Q_{0}$ は $\beta$ 相の固溶領域 の濃度の温度依存性による項を表わす。この考えを適用 すると，本実験では Fig. 1 からもわかるように，ら相は $480^{\circ} \mathrm{C} \sim 560^{\circ} \mathrm{C}$ 温度範囲では $\zeta$ 相の固溶領域の温度依存

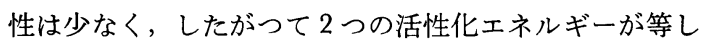
くなつたと考えられる。しかし $360^{\circ} \mathrm{C} \sim 440^{\circ} \mathrm{C}$ の温度範囲 では, ら相の固溶領域の温度依存性が大きいのに, なぜ $2 つ の$ 活性化エネルギーが等しくなったかは検討が必要 だろう。これについては $\mu$ 相の不規則な相成長が，なん らかの影響を与えているとも考えられるが，これまでの データではわからない。また $\mu$ 相の不規則な成長や， 相に比べて成長が著しく遅いことについても, 本実験だ けのデータでは説明することができないだろう。

\section{2 カーケンドール効果}

本実験で行なつたような方法では, 表面拡散の影響を らけるので, カーケンドール効果の厳密な測定はできな い。しかし定性的にはアルミニウムの方が銀より早く应 散するといえる。これは融点の低い金属の方が速く拡散 するという一般の実験結果と一致している。

\section{5. 総 括}

1）平衡状態図から予想された中間相の $\zeta$ 相と $\mu$ 相が それぞれ生成された。

2) ら相の成長は放物線則に従う。

3） 5 相の成長状態は， $\mu$ 相が存在するときと，しな いときとで, その温度依存性に変化はない。

4) 2)から $t$ 相の幅を $W$, 拡散焼鈍時間を $t$ とすると, $W=k \sqrt{t}$ で表わされらる。そしてこの $k$ の温度 依存性法次式のように表わされた。

$$
\begin{aligned}
& k_{1}^{2}=3.1 \times 10^{-1} \exp (-28000 / R T) \mathrm{cm}^{2} / \mathrm{sec} \\
&\left(360^{\circ} \mathrm{C} \sim 440^{\circ} \mathrm{C}: \zeta \text { 相と } \mu \text { 相が共存 }\right) \\
& k_{2}^{2}= 6.6 \times 10^{-1} \exp (-29000 / R T) \mathrm{cm}^{2} / \mathrm{sec} \\
&\left(480^{\circ} \mathrm{C} \sim 560^{\circ} \mathrm{C}: \zeta \text { 相だけが存在 }\right) \\
& k_{3}^{2}= 2.6 \times 10^{-1} \exp (-28000 / R T) \mathrm{cm}^{2} / \mathrm{sec} \\
&\left(360^{\circ} \mathrm{C} \sim 560^{\circ} \mathrm{C}: \text { 全温度範囲 }\right)
\end{aligned}
$$

5) 相の相互扡散俰数の温度依存性は次式で表わさ れる。

$$
\begin{gathered}
D_{1}=2.1 \times 10^{-1} \exp (-27000 / R T) \mathrm{cm}^{2} / \mathrm{sec} \\
\left(360^{\circ} \mathrm{C} \sim 440^{\circ} \mathrm{C}: \zeta \text { 相と } \mu \text { 相が共存 }\right)
\end{gathered}
$$

$$
\begin{aligned}
& D_{2}=2.1 \times 10^{-1} \exp (-27000 / R T) \mathrm{cm}^{2} / \mathrm{sec} \quad(7) \\
& \quad\left(480^{\circ} \mathrm{C} \sim 560^{\circ} \mathrm{C}: \text { 相だけが存在 }\right) \\
& D_{3}=2.5 \times 10^{-1} \exp (-27000 / R T) \mathrm{cm}^{2} / \mathrm{sec} \quad(8) \\
& \quad\left(360^{\circ} \mathrm{C} \sim 560^{\circ} \mathrm{C}: \text { 全温度範囲 }\right)
\end{aligned}
$$

6) カーケンドール効果の測定より，アルミニウムが

銀より速く拡散することが示された。

本研究の一部は軽金属奨学会の補助によつて行なつ た。ここに厚く感謝の意を表します。

\section{参 考 文 献}

1) L. S. Castleman and L. L. Seigle: Trans. AIME 230 (1964), 694.

2) Y. Funamizu and K. Watanabe: Trans. JIM 12 (1971), 147.

3) G. V. Kidson and G. D. Miller: J. Nucl. Mat. 2 (1964), 61.

4）平野-法師：金属学会誌, 32 (1968), 815.

5) W. E. Sweeney and A. P. Batt: J. Nucl. Mat. 13 (1964), 87.

6) Y. Funamizu and K. Watanabe: Trans. JIM 13 (1972), 278.

7) Th. Heumann and S. Dittrich: Z. Electrochem 61 (1957), 1138.

8) M. S. Anard and R. P. Agarwala: Trans. AIME 230 (1964), 694.

9) Th. Heumann and H. Böhmer: J. Phys.Chem. Solids. 29 (1968), 237.

10) H. Bückle: Metallforshg. 1 (1946), 47.

11) H. Bückle: Metallforshg. 1 (1947), 175.

12) M. Hansen: Constitution of Binary Alloys, McGraw Hill, New York, (1958), 1.

13）紀本, 渡辺, 内山：X線マイクロアナライザ 一, 日刊工業.

14) Th. Heumann: Z. Phys. Chem. 201 (1952), 168.

15) T. B. Massalski and B. Cockayne: Acta. Met. 7 (1959), 762.

16) W. B. Pearson: Handbook of Lattice Spacing and Structure of Metals, 391.

17) G. V. Kidson: J. Mat. 3 (1961), 21

18) Y. Funamizu and K. Watanebe: Trans. JIM., 15 (1974), 46. 